Historic, Archive Document

Do not assume content reflects current scientific knowledge, policies, or practices. 

Trees Shipped to all Parts of the United States and Canada from

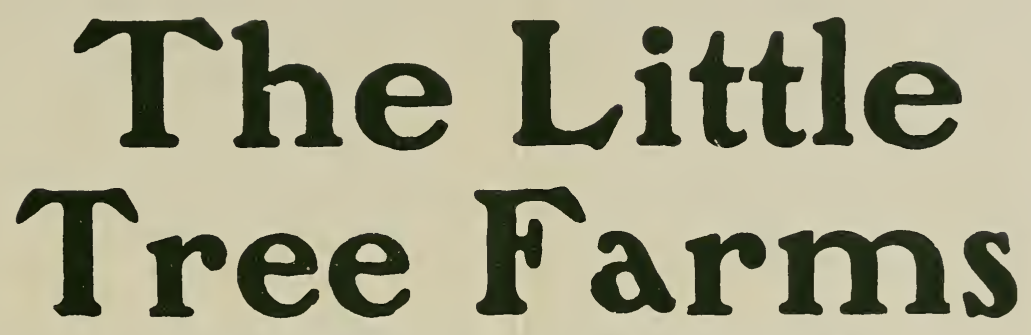

The Birthplace of the Little Grees that Thrive

South Framingham (near Boston), Mass.

Sales Office, 15 Beacon Street, Boston, Mass.

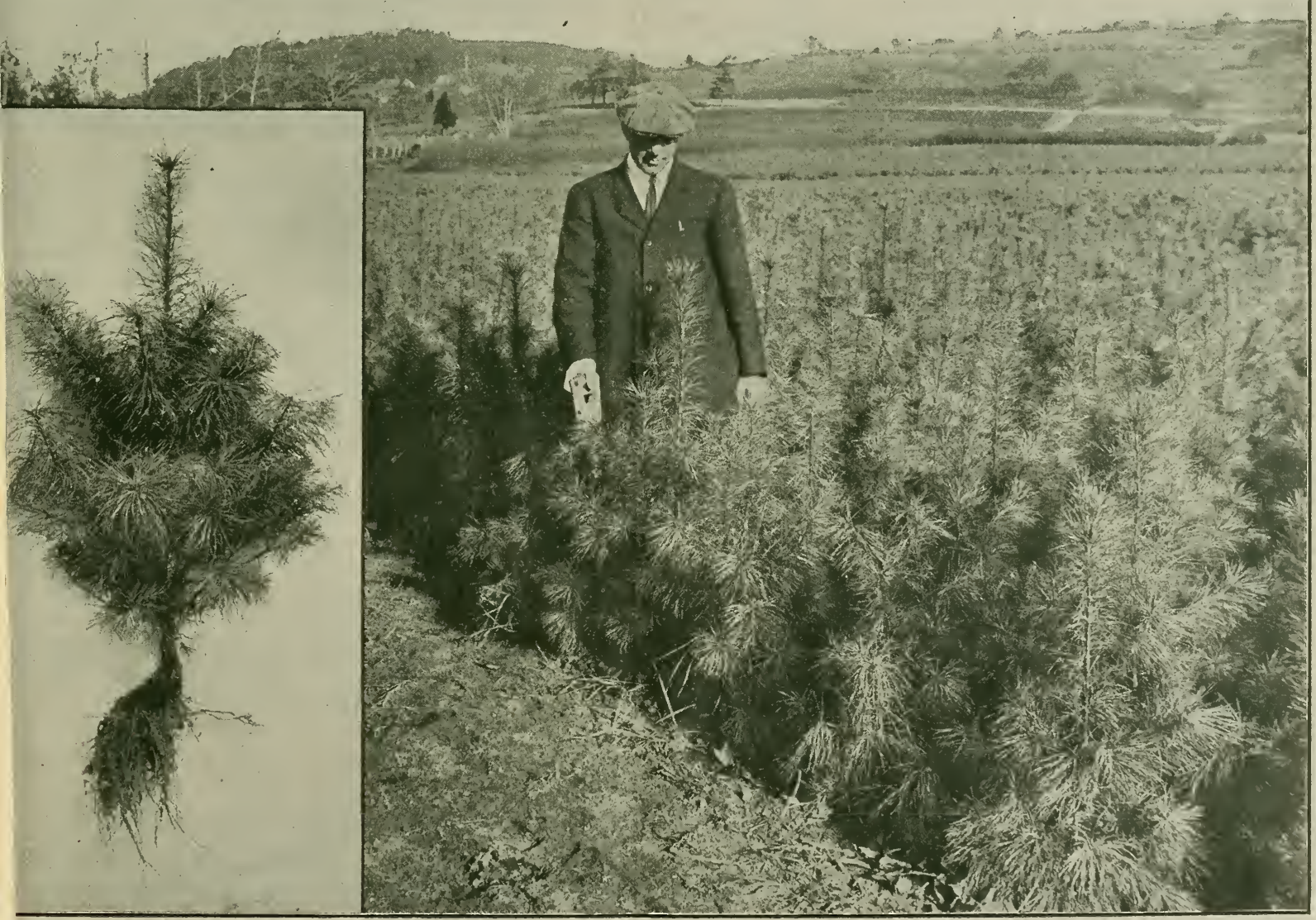

Transplanted White Pines Six Years Old 


\section{The Service of Efficiency}

0 UR Little Tree Farms could not be better situated for the growing of trees or for economy and convenience in shipping. They are located on the Boston and Albany Railroad, main line (New York Central Lines), and on the New York, New Haven and Hartford Railroad, and connected by a short branch with the Boston and Maine Railroad. We deliver free to freights, expresses and mails by auto truck, thus insuring the greatest promptness.

THE Adams and American Express Companies, and connecting agencies, the Western Union Telegraph Company, and the New England Telephone Company, have agents in South Framingham.

WVE use the A. B. C. Telegraph Code, fifth edition, the Western Union Code, and the Nurserymen's Telegraphic Code.

O UR little trees are not exposed to the infection usually surrounding imported stock, for we import nothing. A copy of the Unitcd States Entomologist's certificate of inspection, which assures you of the freedom of our nurseries from plant diseases and pcsts, accompanies each shipment.

W E have a thoroughly modern packing house. In the moist air of a spacious cellar, preventing the dryingout of the roots, the plants are counted and packed. The result of drying-out in the open air often spells failure.

$\mathbf{W}^{\mathrm{E}}$ E ship in bundles of convenient size, carefully tied, and graded according to our catalogue. To avoid confusion, we request our customers kindly to follow cataloguc gradings in ordering.

W E suggest that you order early, that we may ship more promptly and render a better service.

$\mathbf{W}^{\mathrm{H}}$ $\mathrm{E}$ always fill orders in succession of receipt, and never delay early orders to fill late ones,-the only procedure fair to our customers. Better order early, even if not ready to receive, for we will ship the trees when you need them.

$\mathbf{R}^{\prime}$

EMEMBER: our trees are raised from seed and the seed is carefully selected.
TINDLY give complete instructions for marking each 1 shipment. State approximate time of shipment, and designate freight, express, or mail. The new parcels post regulations permit much more extensive use of the mails than has been possible up to this time. In the absence of instructions, we shall use our best judgment. Our responsibility, of course, ceascs upon delivery to the transportation company.

$\mathbf{T}$ HERE is a low spccial express rate on trees, plants, and seeds, which is 20 per ccnt less than regular merchandise charges, but express companies occasionally overlook it.

THE regular spring shipping season usually begins about 1 the end of March, continuing until the first of June. In August and September evergreens are shippcd and our hardwoods about the first of October. Fall shipping may continue until the ground freezcs. The planting season is determined by the condition of trees to be planted. So long as they are dormant they may safely be transplanted. It is safe to ship plants to Southern localities later than would be supposed, because vegetation in Massachusetts is dormant later than farther south

UR terms are cash except by special arrangement. Please remit by draft on Boston or New York banks, if convenient, or send your personal check, or post office or express money order, or cash by registered mail. Customers not rated in Dun's or Bradstreet's, and unknown to us, should enclose 50 per cent of the amount of the bill with order, the plants to be delivered collect on delivery.

W E use the greatest care in following instructions, and our intention and instructions are invariably to send out only first-class plants and secds, true to label, well-packed, and in good condition, but it is obvious that no sale carries any warranty, expressed or implied. We gladly rectify error, if claim is made upon receipt of the goods, but cannot be liable for more than the purchase price. Our reputation and experience are back of every shipment. None of our plants have ever proved untrue to label.

Address all correspondence and orders to AMERICAN FORESTRY COMPANY 15 BEACON ST., BOSTON, MASS., U.S.A. 
To Our Customers:

Our Little Tree Farms, the largest forest nurseries in America, were established seven years ago to supply a more successful product than we could otherwise obtain for the contracting department of the American Forestry Company.

This Company, operating in all lines of forestry work, commercial and esthetic, realized the need of more scientifically grown and climatically adapted plants, in greater numbers and varieties, and at more truly economical prices than could be had in the market.

The Little Tree Farms were the outgrowth of our effort to meet this need. In them we have grown the highest quality of little trees that can be produced, in all the varieties which we find to be hardy and truly valuable in this country, and in sizes best adapted to thoroughly successful planting.

Every one of our little trees is grown according to the recognized principle of seed origin, all of our seeds being collected either by our own men or by tested experts in regions which we specify, and from hardy, vigorous trees.

We do not use chemical fertilizers, nor shade and protection, which give a deceptive appearance of height and color, and make for tenderness and succulence rather than hardiness, "woodiness" and endurance. We transplant by our own tested and careful methods, at proper intervals, and we keep our trees absolutely free from weeds, insect pests, and diseases. Our plants are never exposed to the contagion of imported diseases, for we import nothing.

Furthermore, all of our little trees are kept in the nursery ground until shipping time, when they are dug fresh, packed fresh, and shipped fresh to the customer in as nearly an ideal and perfect condition as is possible to realize. 
In brief, our little trees are fitted to thrive by (1) strict adherence to the scientific and natural principles of seed origin, not widely understood, but absolutejy essential, --the only foundation of real tree success; (2) by growth without the use of chemical or commercial fertilizers or shade or protection and by adaptation to soil; (3) by scientific transplanting and care; (4) by being kept in the nursery ground until shipping time,--dug fresh, packed fresh, and shipped fresh.

When you buy of us, you receive the lowest possible price consistent with the highest quality, and you avoid the pest danger and deterioration of foreign and imported plants.

These are some of the reasons why our little trees give us the best results in our own extensive forest plantings, and why we confidently offer them to you as the best and most economical product for your needs.

Yours sincerely,

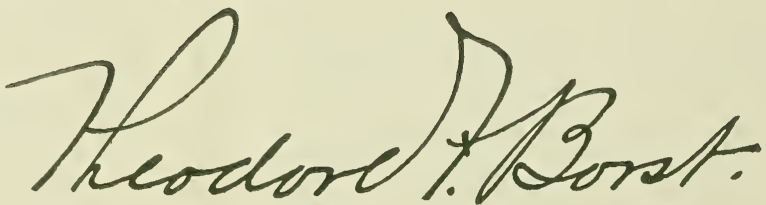

Forest Engineer. 


\section{Tree Department}

\section{CONIFEROUS TREES (Evergreens)}

ABIES BALSAMEA, Mill.

2-yr., Seedling

2-yr., Seedling
Balsam Fir

$\begin{array}{lrr}3 \text { to } 6 \text { in. } & 100 & 1000 \\ 2 \text { to } 3 \text { in. } & .75 & 47.00 \\ \end{array}$

ABIES CONCOLOR, Lindl. \& Gold. Silver, or Concolor

Fir (Colorado seed)

Transplanted .........18 to 24 in. $\$ 20.00 \$ 175.00$

5-yr., Transplanted . . . . . . 12 to 18 in. $16.00 \quad 145.00$

Transplanted ........ 8 to 12 in. $12.00 \quad 100.00$

Transplanted ........4 to 8 in. $7.50 \quad 60.00$

Transplanted .........2 to 4 in. $4.50 \quad 30.00$

Seedling .......... 8 to 12 in. $3.00 \quad 25.00$

Seedling .......... 6 to 8 in. $2.25 \quad 18.00$

Seedling .......... 3 to 6 in. $1.50 \quad 9.00$

Splendid seedlings, well developed and thoroughly hardy, from seeds collected in Rocky Mountains, Colorado. Visiting nurserymen buy in quantity at sight.

\section{JUNIPERUS VIRGINIANA, Linn.}

Juniper: Savin (New England seed)

Twice Transplanted ....12 to 18 in. $\$ 25.00 \$ 225.00$

Twice Transplanted ..... 8 to 12 in. $15.00 \quad 125.00$

Transplanted ......... 18 to 24 in. $18.00 \quad 150.00$

Transplanted .......... 12 to 18 in. $12.00 \quad 100.00$ 3-yr., Transplanted ........ 8 to 12 in. $9.00 \quad 75.00$

2-yr., Seedling ......... 3 to 6 in. $1.75 \quad 15.00$

Our Junipers are all grown from hardy New England seed of our own collecting. They are beautiful little plants, in shape and sturdiness. Dug and shipped the same day.

LARIX EUROPEA, D. C.

Twice Transplanted ..... 3 to $4 \mathrm{ft}$. $\$ 35.00 \$ 275.00$

Twice Transplanted ..... 2 2 to $3 \mathrm{ft} . \quad 18.00 \quad 165.00$

Twice Transplanted ...... 1 to $2 \mathrm{ft} . \quad 10.00 \quad 80.00$

Transplanted ........ 4 to $5 \mathrm{ft} . \quad 20.00$

Transplanted ......... 3 to $4 \mathrm{ft} . \quad 14.00 \quad 120.00$

Transplanted ......... 2 to $3 \mathrm{ft} . \quad 10.00 \quad 80.00$

Transplanted ......... 1 to $2 \mathrm{ft} . \quad 5.50 \quad 40.00$

LARIX LEPTOLEPSIS, Gord.

Japanese Larch

2-yr., Seedling .......... 3 to 6 in. $\$ 2.00 \$ 15.00$

This species is well worth more extensive use. It grows extremely fast.

PICEA ALBA, Link.

Transplanted

Transplanted

Transplanted

Seedling

2-yr., Seedling

Our seedlings were grown from seed from the Maine coast, where the species reaches an unusual development. They are perfectly grown, and splendidly rooted.
White Spruce is one of our best trees-a rapid grower, in demand for ornamental purposes, and having valuable wood.

Letters from many nurserymen speak of perfect results in transplanting them.

PICEA ALBA, Link.

ALBERTIANA, S. Brown.

4-yr., Transplanted

Transplanted

Transplanted

Seedling

Seedling Black Hills.

PICEA ENGELMANNI, Englm.

Twice Transplanted.

Twice Transplanted

Twice Transplanted.

t-yr., Transplanted

Transplanted

3-yr., Seedling

2-yr., Seedling

PICEA EXCELSA, L. K.

Twice Transplanted

Twice Transplanted

Twice Transplanted

Twice Transplanted

Twice Transplanted

Transplanted

Transplanted

Transplanted

Transplanted

Transplanted

Seedling

2-yr., Seedling

Our transplanted stock has earned appreciative letters from careful buyers, and our prices are very low.

\section{PICEA MARIANA, (Mill) B. S. P NIGRA (Link)}

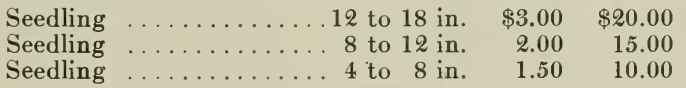

Well grown, well hardened off seedlings; they will please you. They are all grown of Maine seeds and will thrive when set out.

PICEA RUBRA, (Lamb.) Link. NIGRA, var. rubra (Engelm).

Northern or Red Spruce, also ("Black Spruce")

Transplanted ........8 to 12 in. $\$ 3.00$

Transplanted ........ 4 to 8 in. $\quad 2.00$

$\$ 25.00$

Seedling ........... 12 to 18 in. 2.0

Seedling $\ldots \ldots \ldots \ldots \ldots .8$ to 12 in. 1.50

18.00

Seedling ...........4 to 8 in. $1.00 \quad 5.00$

This splendid native tree deserves far more general use. We have nice stock at low prices.

PICEA PUNGENS, Englm. (Nursery run.) Colorado Blue Spruce

Twice Transplanted

Twice Transplanted.

Twice Transplanted

Twice Transplanted.

$\begin{array}{rrr}18 \text { to } 24 \text { in. } \$ 25.00 & \$ 200.00 \\ 12 \text { to } 18 \text { in. } & 15.00 & 125.00 \\ 8 \text { to } 12 \text { in. } & 10.00 & 75.00 \\ 4 \text { to } 8 \text { in. } & 5.00 & 40.00\end{array}$

18 to 24 in. $\$ 25.00 \$ 200.00$ 8 to 12 in. 10.00 40.00 
PICEA PUNGENS, Englm. (Nursery run.) (Continued)

Transplanted

Transplanted

Transplanted

Seedling

Seedling

Seedling

Colorado Blue Spruce

100

12 to 18 in. $\$ 10.00 \$ \$ 80.00$

8 to 12 in.

4 to 8 in. $3.25 \quad 27.50$

12 to 18 in. $\quad 3.00 \quad 20.00$

8 to 12 in. $2.00 \quad 15.00$

4 to 8 in. $1.25 \quad 8.00$

We have perfect plants, with bushy, dense tops and heavy, fibrous roots. We grew them from seed of blue trees. Seed collected in Colorado. They are sold "nursery run." None of the bluest ones have been picked out. Having the largest supply of these fine specimens in the country, we are making the lowest prices.

\section{PINUS AUSTRIACA, Hoss.}

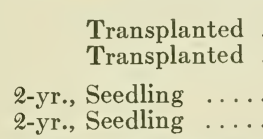

PINUS CONTORTA, Loud.

3-yr., Seedling

3-yr., Seedling

\begin{tabular}{|crr|}
\multicolumn{4}{c}{ Austrian Pine } \\
8 to 12 in. & 100 & \multicolumn{1}{c|}{1000} \\
4 to 8 in. & 3.50 & $\$ 50.00$ \\
4 to 6 in. & 1.00 & 30.00 \\
2 to 4 in. & .75 & 4.00
\end{tabular}

\section{Shore Pine}

.12 to $18 \mathrm{in}$. $\$ 10.00$ 6 to 12 in. $\quad 5.00$
$\$ 75.00$ 40.00

\section{PINUS DIVARICATA, Du Mont. syn. Bank's Pine}

\section{BANKSIANA, Lamb.}

Twice Transplanted.

Twice Transplanted.

5 to $6 \mathrm{ft} . \quad \$ 12.50 \quad \$ 100.00$

Transplanted ...........18 to 24 in. $\quad 5.00$

Transplanted ........... 12 to 18 in. $\quad 3.00$

No more unusual offer has ever been made-Large evergreens at a little price. They will thrive on the poorest, driest soils, in the most exposed places.

Bank's Pine is beyond question a rapid grower. It deserves its popular names-" "the sudden sawlog," the "poplar of the Evergreens." It is certainly a good tree for "immediate results." We have a large supply and can sell them at a price you could not dig them for,-five to ten cents apiece. The Bank's Pine is the hardiest native evergreen tree we have, and is especially adapted to dry, loose soil, where it has a wondrous power of withstanding drought. It is of rapid growth when young, which, together with its great hardiness, has led to its being planted on some of the sandiest dry lands of the country. It is very valuable for such locations. It often acts as a nurse tree for the Red Pine and others.

It is one of the first evergreens to start on the abandoned dry pine land in many sections. It will thrive on the poorest, driest soils, in the most exposed places.

A very pronounced peculiarity of this tree is its habit of forming several whorls of branches on the new growth. This is especially noticeable when the trees are young and growing rapidly, when as many as six whorls of branches may be seen on a year's growth. This tree, under favorable conditions, will occasionally attain a height of 125 feet and a diameter of two feet. However, it is seldom over seventy feet high and eight to twelve inches in diameter, and generally where it occurs in pine forests it is only forty or fifty feet high. Much of it is used for fencing, farm buildings, railroad ties, and as fuel. When young it grows twice as fast as the white pine.

PINUS FLEXILIS, James.

Limber Pine, Western White Pine $100 \quad 1000$ Transplanted ........4 to 8 in. $\$ 5.00 \quad \$ 40.00$

Seedling . . . . . . 3 to 6 in. $1.75 \quad 12.00$
2-yr., Seedling $\ldots \ldots \ldots \ldots \ldots \ldots 2$ to 3 in. $1.00 \quad 7.00$

\begin{tabular}{|c|c|c|c|}
\hline & \multicolumn{3}{|c|}{$\begin{array}{l}\text { Limber Pine, West- } \\
\text { ern White Pine }\end{array}$} \\
\hline 4. to & 8 in. & $\begin{array}{c}100 \\
\$ 5.00\end{array}$ & $\begin{array}{r}1000 \\
\$ 40.00\end{array}$ \\
\hline & $6 \mathrm{i}$ & 1.75 & 12.00 \\
\hline 0 & $3 \mathrm{in.}$ & 1.00 & 7.00 \\
\hline
\end{tabular}

LARGE ORDERS ARE SUBJECT TO A DISCOUNT
PINUS LARICIO, Poir.

Corsican Pine

2-yr., Seedling

100

1000

PINUS MONTICOLA, Dougl.

2 to 3 in. $\$ 0.75$

$\$ 4.00$

Silver or Western White Pine (Mountain Pine)

Transplanted ........4 to 8 in. $\$ 4.00 \$ 35.00$

Seedling ......... 1 to 2 in. $.75 \quad 5.00$

\section{PINUS MUGHUS, Scop., MONTANA \\ Dwarf Mountain
Pine}

Transplanted

3 to 6 in.

$\$ 5.00$

$\$ 40.00$

Seedling

1 to 3 in.

.75

6.00

PINUS MURRAYANA, “Oreg. Com.” Lodgepole Pine Seedling ...........2 to 4 in. $\$ 1.00 \quad \$ 5.00$

PINUS RESINOSA, Ait.

Red, or Norway Pine Transplanted ........12 to 18 in. $\$ 8.50 \quad \$ 70.00$ Transplanted ......... 8 to 12 in. $\quad 5.00 \quad 40.00$ Transplanted ........ 6 to 8 in. $\quad 3.00 \quad 20.00$ Transplanted ........4 to 6 in. $2.00 \quad 15.00$

3-yr., Seedling .......... 8 to 12 in. $2.50 \quad 20.00$ 3-yr., Seedling $\ldots \ldots \ldots \ldots \ldots \ldots .6$ to 8 in. $2.00 \quad 12.00$ 2-yr., Seedling ...........4 to 6 in. $1.25 \quad 7.00$ 2-yr., Seedling .......... 3 to 4 in. $\quad 1.00 \quad 4.00$ The best rooted and developed seedlings of this species we have ever grown-guaranteed true resinosa.

This species has been scarce in the market for several years, and substitution of other species has been known. We have a large supply of stocky, finely grown, and unusually well-rooted seedlings. Visiting nurserymen have bought them at sight. Considering the high price of the seeds these plants are extremely cheap.

The Red Pine is one of the most valuable native trees for general planting. It grows faster than the White Pine, often on poorer and more wind-swept soils. It withstands salt air and spray as few other trees do. It is picturesque even on poor soils and on richer soils its vigorous, long, deep green needles are superb. The wood of this species is valuable and is being more appreciated every year.

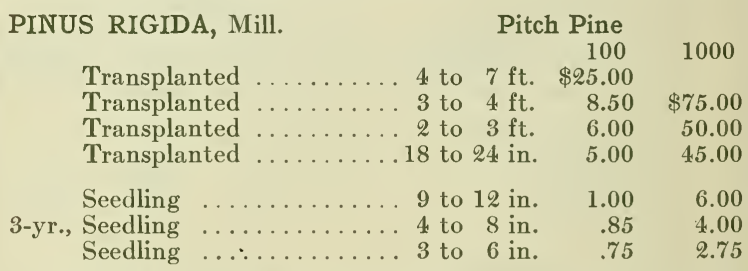

This is the most enduring of our native pines under adverse conditions of soil, exposure and drought. On good soils it thrives, and is considered by many owners a most picturesque tree.

\section{PINUS STROBUS, Linn.}

White Pine

Twice Transplanted..... 3 to $4 \mathrm{ft}$. $\$ 25.00 \quad \$ 200.00$

Twice Transplanted...... 2 to $3 \mathrm{ft} . \quad 18.00 \quad 175.00$

Twice Transplanted..... 18 to 24 in. $10.00 \quad 80.00$

Twice Transplanted..... 12 to 18 in. $8.00 \quad 60.00$

Twice Transplanted..... 8 to 12 in. $4.00 \quad 30.00$

Transplanted ........ 3 to $4 \mathrm{ft}$. $12.00 \quad 100.00$

Transplanted ......... 2 to $3 \mathrm{ft} . \quad 9.00 \quad 75.00$ 5-yr., Transplanted ......... 18 to 24 in. $\quad 7.50 \quad 60.00$

Prominent nurserymen have said that we have the finest supply in America. This tree cannot longer be imported, 
PINUS STROBUS, Linn

(Continued)

White Pine

owing to the dreaded "blister rust" in Europe. We have a splendid supply, and should have your orders.

During the American Nurserymen's Convention in Boston many of America's best growers visited the "LITTLE TREE FARMS," and declared our stock as fine as they had ever seen.

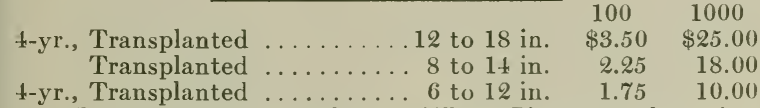

Four-year old transplanted White Pines are the safest trees for general use in reforesting idle lands; they are the surest to grow. These are heavy, stocky trees, with good tops and a mass of fibrous roots.

Transplanted (Heavy)... . 5 to 8 in. $\$ 1.50 \quad \$ 8.00$ Transplanted ......... \& to 8 in. $1.00 \quad 6.00$ 3-yr., Transplanted ........ 3 to $t$ in. $\quad .80 \quad 5.00$

This size is splendid for underplanting, and will stand shading as well as dry exposures. They are sure to live and thrive.

Seedling $\ldots \ldots \ldots \ldots \ldots 12$ to 18 in. $\$ 1.50 \$ 10.00$ Seedling ............ 8 to 12 in. $1.25 \quad 7.00$

Our seedlings are as well rooted as the cheaply produced, chemically nourished transplants recently brought into the market. We have improved our seedlings so that we can now offer in them a better value than the low grade transplant of competition.

3-yr., Seedling $\ldots \ldots \ldots \ldots \ldots 6$ to 8 in. $\$ 1.00 \quad \$ 5.00$

These are the most successful three-year seedlings we have ever grown. They are vigorous, and the price is extremely low.

3-yr., Seedling No. 1 quality ... 4 to 6 in. $\$ 0.85 \$ 3.00$

This is a good grade of three-year seedlings, with good roots. They are certainly a bargain at these prices.

Seedling, No. 1 quality . . 3 to 5 in. $\$ 0.75 \quad \$ 2.25$ 2-yr., Seedling, good quality .... (a verage size) $\quad 2.00$

Our seedlings are raised from seed of our own collecting from a perfect stand of thinned timber in New Hampshire. They are hardened off and abundantly rooted, stocky and well balanced in top and root. Do not forget that in cataloguing only the height is given; a lank, over-stimulated plant of the same "size" cannot compare with our sturdy, naturally grown trees, for real quality.

\section{PINUS SYLVESTRIS, A.}

\section{Scotch Pine}

100

1000

Twice Transplanted..... . t to $5 \mathrm{ft} . \quad \$ 18.00 \$ 150.00$

Twice Transplanted ..... 3 to $4 \mathrm{ft}-10.00$

Twice Transplanted.....2 2 to $3 \mathrm{ft}$. $8.00 \quad 70.00$

Twice Transplanted..... 18 to 24 in. $7.00 \quad 60.00$

Transplanted .........5 to $7 \mathrm{ft}$. $20.00 \quad 175.00$

Transplanted .......... 4 to $5 \mathrm{ft} . \quad 15.00 \quad 135.00$

Transplanted ......... 3 to $4 \mathrm{ft}$. $8.00 \quad 70.00$

Transplanted .......... 2 to $3 \mathrm{ft} . \quad 6.00 \quad 50.00$

Transplanted ......... 12 to 24 in. $\quad 4.50 \quad 40.00$

Our plants are well rooted, and were all grown from seeds at the "Little Tree Farms." Our success with Scotch Pine has been commented upon by experienced nurserymen.

Recently a number of state and private foresters have set out large quantities, and the trees are growing rapidly. Scotch Pine is the pine of Europe, and the wood is highly valued there. It is used for a great variety of purposes, and brings good prices.

PSEUDOTSUGA TAXIFOLIA, Britt. syn., DOUGLASII, Carr.

Douglas Spruce

(Rocky Mt. seeds)

Transplanted

Transplanted

4 to 8 in. $\$ 2.00$

$\$ 2.00$

Seedling

Seedling

Seedling

2 to $t$ in.

1.50

8 to 12 in

1.25

4 to 8 in

1.25
.90

2 to 3 in

.75

1000

$\$ 15.00$

8.00

12.00

7.00

$+.00$

3.00

These little trees were raised from Rocky Mountain Colorado seed, and are perfectly vigorous and hardy, as well as painstakingly grown. They are straight, well topped, well rooted; nicer plants can't be had. In anticipation of the annually increasing demand we have grown a million little trees of this most valuable, beautiful and adaptable species. The Douglas is one of the most majestic trees of North America, and has found favor wherever introduced, here and in Europe.

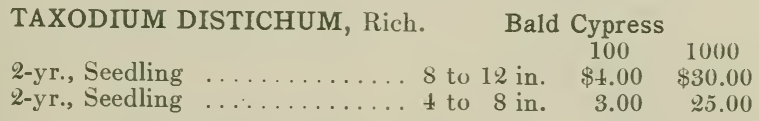

TAXUS CUSPIDATA BREVIFOLIA. Japanese Yew Several times Transplanted Each $10 \quad 100$ 20 to 24 in. $\$ 3.00 \$ 25.00$

Several times Transplanted 16 to 20 in. $2.50 \quad 20.00$

Several times Transplanted 12 to 16 in. $\quad 1.25 \quad 10.00 \quad \$ 85.00$

Several times Transplanted

8 to 12 in. $\quad .75 \quad 6.50 \quad 50.00$

A splendid compact plant, a hardy, satisfactory ornamental.
THU JA OCCIDENTALIS, Linn.
Arborvitae; White Cedar
Transplanted
4 to 8 in.
3 to 6 in.
$\begin{array}{cc}100 & 1000 \\ \$ 1.50 & \$ 12.00\end{array}$
3-yr., Seedling
3 to 6 in. 1.00
5.00
2-yr., Seedling
2 to 4 in.
.75
3.00
THUJA ORIENTALIS
2-yr., Seedling
Oriental Arborvitae
TSUGA CANADENSIS, Carr.
2-yr., Seedling
3 to 6 in. $\$ 1.50 \quad \$ 10.00$
Hemlock (Northern seed)
1 to 2 in. $\$ 1.00$
$\$ 8.00$

\section{BROAD-LEAVED TREES (Deciduous)}

\section{ACER DASYCARPUM, Ehr., syn. SACCHARINUM \\ Seedling \\ ACER NEGUNDO, Linn. \\ Transplanted \\ Transplanted \\ Transplanted \\ Transplanted \\ Transplanted \\ Transplanted \\ Transplanted \\ Seedling}

ACER PLATANOIDES, Linn.

Transplanted

Transplanted
Silver Maple

100

2 to 4 in. $\$ 0.65$

1000

Box Elder

9 to $11 \mathrm{ft}$. $\$ 12.00$

7 to $9 \mathrm{ft} . \quad 8.50$

5 to $7 \mathrm{ft}$. $\quad 7.00$

4 to $5 \mathrm{ft}$. $\quad 5.00$

3 to $+\mathrm{ft}$. $\quad 3.50$

2 to $3 \mathrm{ft} . \quad 2.50$

18 to 24 in. 2.00

2 to $t$ in.

.50

$\$ 85.00$ 65.00 55.00 40.00 30.00 20.00 15.00

3.00

Norway Maple

t to $6 \mathrm{ft}$. $\$ 7.00$

3 to $4 \mathrm{ft} . \quad 5.00$ 


\section{(Continued)}

Transplanted

Transplanted

Transplanted

Transplanted

Seedling

Seedling

Seedling

Seedling

We have a large supply of thrifty, stock
the with straight tops. The price is low.

\section{ACER PSEUDO-PLATANUS, Linn.}

Sycamore Maple

Transplanted
Transplanted
Transplanted ...
Transplanted ...
Transplanted ...
Transplanted ...
Seedling ....
Seedling ....
Seedling ....

ACER RUBRUM, Linn.

\section{Transplanted}

Transplanted

Transplanted

Transplanted

Transplanted

Seedling

These are nice str of our own collecting.

\section{ACER SACCHARUM, Marsh.}

Transplanted $\ldots \ldots \ldots \ldots$
Transplanted $\ldots \ldots \ldots \ldots$
Transplanted $\ldots \ldots \ldots \ldots$
Seedling $\ldots \ldots \ldots \ldots \ldots \ldots$
Seedling $\ldots \ldots \ldots \ldots \ldots$
Seedling $\ldots \ldots \ldots \ldots \ldots$
Seedling $\ldots \ldots \ldots \ldots \ldots$

$\begin{array}{lrr}5 \text { to } 7 \mathrm{ft} . & \$ 12.00 & \\ 3 \text { to } 4 \mathrm{ft} . & 8.00 & \\ 2 \text { to } 3 \mathrm{ft} . & 5.00 & \\ 1 \text { to } 2 \mathrm{ft} . & 3.00 & \$ 20.00 \\ 8 \text { to } 12 \mathrm{in} . & 2.25 & 18.00 \\ 4 \text { to } 8 \mathrm{in} . & 2.00 & 15.00 \\ 1 \text { to } 2 \mathrm{ft} . & 1.50 & 10.00 \\ 8 \text { to } 12 \mathrm{in.} & 1.00 & 5.00 \\ 4 \text { to } 8 \mathrm{in} . & .90 & 3.00\end{array}$

\section{Red Maple}

5 to $7 \mathrm{ft}$. $\$ 15.00 \$ 125.00$

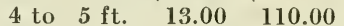

$\begin{array}{llll}3 \text { to } & 4 \mathrm{ft} . & 8.00 & 70.00\end{array}$

$\begin{array}{llll}2 \text { to } & 3 \mathrm{ft} . & 6.00 & 50.00\end{array}$

1 to $2 \mathrm{ft}$. $\quad 3.50 \quad 30.00$

1 to $2 \mathrm{ft} . \quad 1.00 \quad 7.50$
BETULA PAPYRIFERA, Marsh. Birch

Transplanted ......... 1 to $2 \mathrm{ft}$.

Transplanted .......6.6 to 12 in. 3 to 6 in.
Paper, or Canoe ch

$100 \quad 1000$

$\$ 8.00 \quad \$ 65.00$

$5.00 \quad 40.00$

$3.00 \quad 25.00$

CARYA (See Hicoria).

CASTANEA DENTATA, Borkh., syn. American Sweet AMERICANA, Rafin.

Chestnut

Transplanted ........ 5 to $7 \mathrm{ft} . \$ 10.00$

Transplanted ......... 3 to $5 \mathrm{ft} . \quad 5.00 \quad \$ 40.00$

Transplanted .......... 1 to $3 \mathrm{ft} . \quad 3.50 \quad 25.00$

Our chestnuts are going rapidly, owing to the low price. The trade bought large quantities for grafting for Paragon chestnuts, etc. We shall complete the clearing of this land this spring.

CATALPA SPECIOSA, Warder

Twice Transplanted

Twice Transplanted

seed

Grown from seed locally collected by our own men. We sell thousands of these every year to nurserymen on "repeat orders."

\section{AESCULUS GLABRA, Willd. HIPPOCASTANUM}

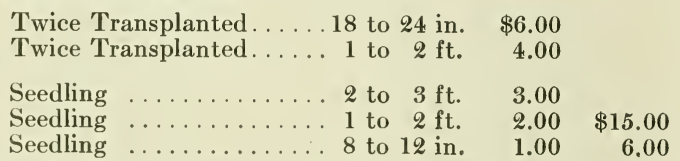

These are very heavy, full of life, little trees, perfectly straight tops, heavily budded, and are very well rooted.

\section{BETULA ALBA, Linn.}

Transplanted

Transplanted

BETULA LUTEA, Michx.

Transplanted

Transplanted

Transplanted

\section{White Birch}

1 to $2 \mathrm{ft}$. $\$ 4.00$

6 to 12 in. 1.50

\section{Yellow Birch}

3 to $4 \mathrm{ft}$. $\$ 15.00 \$ 100.00$

2 to $3 \mathrm{ft} . \quad 10.00 \quad 80.00$

1 to $2 \mathrm{ft}$. $\quad 8.00 \quad 65.00$
$\$ 85.00$

50.00

2.00

8.00

3.00

50

$\begin{array}{lrr}3 \text { to } 4 \mathrm{ft} . & \$ 10.00 & \$ 85.00 \\ 2 \text { to } 3 \mathrm{ft} . & 7.50 & 65.00 \\ 1 \text { to } 2 \mathrm{ft} . & 6.00 & 50.00 \\ & & \\ 1 \text { to } 2 \mathrm{ft} . & 2.00 & 12.00 \\ 8 \text { to } 12 \mathrm{in} . & 1.50 & 8.00 \\ 4 \text { to } 8 \mathrm{in} . & 1.00 & 3.00 \\ 2 \text { to } 4 \text { in. } & .75 & 2.50 \\ \text { ected by our own men. } & \text { We } \\ \text { ro nurserymen on "repeat }\end{array}$

\section{Horse Chestnut}


HICORIA GLABRA, Britt.; syn.,

Pignut (Hickory)

CARYA PORCINA, Nutt.

$$
100
$$

1000

Transplanted ......... 8 to 12 in. $\$ 6.00$

Transplanted ..........4 to 8 in 4.00

Seedling $\ldots \ldots \ldots \ldots, 8$ to 12 in.

Seedling $\ldots \ldots \ldots \ldots \ldots 4$ to 8 in.

4.00

3.00

$2.00 \$ 15.00$

HICORIA LACINOSA, Sarg.

Big Shellbark

CARYA SULCATA, Nutt.

Transplanted ........ 18 to 24 in. $\$ 10.00$

Transplanted ......... 12 to 18 in. 8.00

$\begin{array}{llllr}\text { Seedling } \ldots \ldots \ldots \ldots \ldots \ldots & 3 \text { to } 4 \mathrm{ft} . & 6.00 & \$ 50.00 \\ \text { Seedling } \ldots \ldots \ldots \ldots \ldots \ldots & 2 \text { to } 3 \mathrm{ft} . & 4.50 & 35.00 \\ \text { Seedling } \ldots \ldots \ldots \ldots \ldots \ldots & 1 \text { to } 2 \mathrm{ft} . & 3.00 & 20.00\end{array}$

HICORIA OVATA, Britt.; syn., Shellbark; Shagbark CARYA ALBA, Nutt.

\section{Hickory}

Twice Transplanted.....2 2 to $2 \frac{1}{2} \mathrm{ft}$. $\$ 50.00$

Transplanted

$\begin{array}{rrr}\text { Transplanted } \ldots \ldots \ldots \ldots \ldots 18 \text { to } 24 \text { in. } & 20.00 & \$ 175.00 \\ \text { Transplanted } \ldots \ldots \ldots \ldots \ldots 12 \text { to } 18 \text { in. } & 15.00 & 125.00\end{array}$

Transplanted ........ 8 to 12 in. $10.00 \quad 80.00$

Transplanted ......... 4 to 8 in. $\quad 6.00$

Seedling (heavy rooted) .. 3 to $4 \mathrm{ft}$. $\quad 8.00$

Seedling (heavy rooted) . . 2 to $3 \mathrm{ft}$. $\quad 5.00 \quad 40.00$

Seedling (heavy rooted) .. 1 to $2 \mathrm{ft}$. $\quad 4.00 \quad 30.00$

Seedling (heavy rooted) $\ldots 8$ to 12 in. $3.00 \quad 20.00$

Seedling (heavy rooted) $\ldots 4$ to 8 in. $\quad 2.00 \quad 12.00$

Prices very low. We are supplying the trade for "grafting" stock year after year. This tree deserves much more use.

LARIX (See under Coniferous Trees)

QUERCUS BICOLOR, Willd.

Swamp White Oak

Transplanted ........ 5 to $6 \mathrm{ft} . \$ 30.00$

Transplanted ......... 4 to $5 \mathrm{ft} . \quad 20.00$

Transplanted ......... 3 to $4 \mathrm{ft}$. $\quad 16.00$

Transplanted .......... \& to $3 \mathrm{ft} . \quad 12.00$

Transplanted ........ 1 to $2 \mathrm{ft} . \quad 10.00$

$\$ 80.00$

Seedling ..........4 to $5 \mathrm{ft}$.

9.00

8.00

Seedling $\ldots \ldots \ldots \ldots \ldots 3$ to $4 \mathrm{ft}$

6.00

$3.50 \quad 25.00$

Seedling .......... 1 to $2 \mathrm{ft}$

$\begin{array}{ll}3.50 & 18.00\end{array}$

Seedling ............ 8 to 12 in.

Seedling $\ldots \ldots \ldots \ldots \ldots .4$ to 8 in. $1.75 \quad 10.00$
This is a valuable oak and is gaining in demand. We have a fine supply at low prices.

QUERCUS COCCINEA, Muench.

Scarlet Oak

Transplanted ......... 3 to $4 \mathrm{ft}$. $\$ 25.00$

Transplanted .......... 2 to $8 \mathrm{ft} . \quad 20.00$

Transplanted .......... 1 to $2 \mathrm{ft} . \quad 10.00$

Transplanted ........ 8 to 12 in. $\quad 8.00$

$\$ 60.00$

Seedling $\ldots \ldots \ldots \ldots \ldots 2$ to $3 \mathrm{ft} . \quad 10.00 \quad 90.00$

Seedling $\ldots \ldots \ldots \ldots \ldots \ldots 1$ to $2 \mathrm{ft} . \quad 6.00 \quad 50.00$

Seedling $\ldots \ldots \ldots \ldots \ldots .8$ to 12 in. $2.95 \quad 20.00$

QUERCUS MACROCARPA, Michx. Bur Oak

Transplanted .........4 to $6 \mathrm{ft}$. $\$ 15.00 \$ 100.00$

Transplanted $\ldots \ldots \ldots \ldots \ldots .3$ to $4 \mathrm{ft} . \quad 10.00 \quad 80.00$

Transplanted .......... 2 to $3 \mathrm{ft} . \quad 7.00 \quad 60.00$

Transplanted .......... 1 to $2 \mathrm{ft} . \quad 6.00 \quad 50.00$

LARGE ORDERS ARE SUBJECT TO A DISCOUNT

(13)

QUERCUS MACROCARPA, Michx. Bur Oak

(Continued)

\begin{tabular}{|c|c|c|c|c|}
\hline & & & 100 & 1000 \\
\hline dling & 4 to & $5 \mathrm{ft}$. & $\$ 6.00$ & $\$ 50.00$ \\
\hline Seedling & 3 to & $4 \mathrm{ft}$. & 4.00 & 30.00 \\
\hline Seedling & .. 2 to & $3 \mathrm{ft}$. & 3.00 & 20.00 \\
\hline
\end{tabular}

QUERCUS PALUSTRIS, Muench. Pin Oak

Transplanted ........ 5 to $7 \mathrm{ft} . \quad \$ 25.00 \$ 185.00$

Transplanted .........4 to $5 \mathrm{ft} . \quad 15.00 \quad 115.00$

Transplanted .......... 3 to $4 \mathrm{ft} . \quad 8.50 \quad \mathbf{7 5 . 0 0}$

Transplanted .........2 to $3 \mathrm{ft} . \quad 7.50 \quad 65.00$

Transplanted ......... 1 to $2 \mathrm{ft} . \quad 7.00 \quad 60.00$

Our Pin Oaks don't need to be "cut back" when set out; they have sufficient root to support the top. At "Little Tree Farms" we have learned how to produce Oaks with fibrous roots. The Pin Oak is steadily gaining in popularity. It grows quickly, has perfect shape, and endures well under many conditions. It has a vivid fall coloring.

QUERCUS RUBRA, Linn.

\section{Red Oak}

$100 \quad 1000$

Transplanted

Transplanted

Transplanted

Transplanted

Transplanted

Transplanted

Seedling $\ldots . .$.

Seedling

Seedling

Seedling

Seedling

Our Red Oaks are unusually fine; we sell them at the very lowest price because we can grow them cheaply. This is the coming oak for ornamental as well as commercial planting. The rapid growth, persistent and altogether satisfactory development of the Red Oak, as well as its beauty and its large volume of valuable wood, make this a tree of the first class. Its adaptability is proven by its wide natural range.

QUERCUS VELUTINA, Lamb.

Black Oak

100

1000

Transplanted

Transplanted

Transplanted

Transplanted

Seedling

Seedling

7 to $9 \mathrm{ft} . \quad \$ 30.00 \$ 275.00$

$\begin{array}{rrrr}5 \text { to } & 7 \mathrm{ft} . & 15.00 & 115.00 \\ 4 \text { to } & 5 \mathrm{ft} . & 10.00 & 85.00\end{array}$

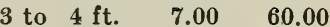

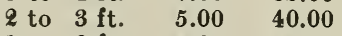

1 to $2 \mathrm{ft}$. $\quad 3.25-25.00$

5 to $8 \mathrm{ft}$

7.00

55.00

$3.50 \quad 25.00$

$2.50 \quad 15.00$

00

These are very vigorous, unusually good stock and yery heap, - unusual both in quality and price.

\section{SALIX PURPUREA}

\section{Purple or Welsh Willow}

Heavy Rooted Plants .... 3 to $5 \mathrm{ft}$. $\$ 10.00$

Cuttings ................ About $1 \mathrm{ft}$. $\quad .75$

A very rapidly growing species, which endures conditions well. These are dense, heavy clumps of root.

\section{SALIX VIMINALIS}

Heavy Rooted Plants.... . 4 to $6 \mathrm{ft}$. $\$ 10.00$

Heavy Rooted Plants.... . 3 to $4 \mathrm{ft}$. $\quad 7.00$

Cuttings................ About $1 \mathrm{ft}$. $\quad .75$ string for tying bundles of plants; it does not cut the bark when drawn tight. We brought this kind from Europe originally, after careful study of the best kinds in use. 


\section{Tree Seed Department}

1. HE American Forestry Company has large experience in the collecting, extracting, care and sowing of seed.

We have made a study of the influence of seed origin on the resulting hardiness of trees and on their silvical character, and we use our knowledge of this subject constantly in our nurseries and seed business. We are prepared to supply seed from specified regions, and to inform our customers of the regional origin of seed supplied by us, and its fitness for use in other specified regions. The seed of those trees which are hardiest and best in our vicinity is collected in Massachusetts by our own men. That which must come from other regions to be of the best source is gathered by tested collectors, and under our instructions. The most critical of foreign seed journals mentions our knowledge of seed origin with commendation.

We supply absolutely the best seed obtainable of the season's crop. Since we sow large amounts annually in our nurseries we can use any surplus, and are therefore always able to offer fresh seeds. Seed supplied by us is fresh, well cleaned and of good germinating quality.

Order Now. We beg to remind you that the finest quality of seed can be obtained only by collecting immediately after it ripens; many kinds deteriorate rapidly. Some seeds ripen very early in the summer and the later varieties must be gathered before the severe weather makes the work of collecting unduly expensive and difficult. Place your order early, and so give us the opportunity to meet your requirements fully, promptly and economically.

Shipping instructions are requested. With every order please give full directions for marking the package, and state whether we shall ship by mail, express or freight. In the absence of instructions we shall use our best judgment; in all cases our responsibility ceases upon delivery to the forwarding agent.

Our terms are cash, except by special arrangement. Payments should be made by draft on Boston or New York banks, bank cheque, post office or express money order, or cash in registered letter. If shipment is to be made by mail add 9 cents per pound for points in the United States, and 18 cents per pound for points in Canada. Registration (if desired) 10 cents per package additional. Bagging and boxing are charged for at cost.

\section{Prices may change without notice.}

We can supply other seeds than those catalogued.

Orders accepted subject to crop conditions and receipt of seeds.

Special quotations will be made on requirements submitted early in the season, or for large quantities. 
ABIES AMABILIS Forb. ARIZONICA

BALSAMEA Mili. .

CONCOLOR Lindl.

$$
6
$$

FIRMA Sieb. et Zucc.

FRASERI Lindl...

GRANDIS Lindl.

MAGNIFICA Murr.

NOBILIS Lindl.

NORDMANNIANA Link

PECTINATA, D. C.

SIBIRICA Ledeb.

CUPRESSUS MACROCARPA Hartw........... Monterey Cypress

GINKGO BILOBA Linn.

JUNIPERUS BARBADENSIS Linn.

COMMUNIS Linn.

MONOSPERMA Englm.

OCCIDENTALIS Hook.

SABINA Linn.

VIRGINIANA Linn.

"،

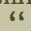

LARIX AMERICANA Michx.

or LARICINA Koch.

EUROPEA D. C.

LEPTOLEPSIS Gord.

OCCIDENTALIS Nutt.

SIBIRICA Led.

LIBOCEDRUS DECURRENS Torr.

PICEA ALBA Link.

$$
\text { "6 }
$$

ENGELMANNI Englm

EXCELSA Link.

MARIANA Link

or NIGRA Mill.

PUNGENS Englm.

or PARRYANA Andre.

RUBENS Sarg.

\author{
..
}

AUSTRIACA Ho

COULTERI Lamb.

DENSIFLORA Siebold

DIVARICATA DuMont.

or BANKSIANA Lamb. . ECHINATA Mill.

or MITIS Michx.

EDULIS Englm. .

EXCELSA Wall.

FLEXILIS James

INSIGNIS Dougl.

or RADIATA D. Don..

JEFFREYI "Oreg. Com."

LAMBERTIANA Dougl.

LARICIO Poir.

MARITIMA Poir.

MASSONIANA Lamb.

MONOPHYLLA Poir.

MONTICOLA Dougl.

MUGHUS Scop.

American Larch.
Amabilis Fir

Arizona Cork Fir

. Balsam Fir

Silver Fir

Japanese Silver Fir

Fraser Fir.

Lowland Fir

Red Fir

Noble Fir

Nordmann's Fir.

European White Fir

Sibirian Fir

Port Oxford Cedar

White Cedar ....

Maidenhair Tree.

Origin of Seed

Southern Red Cedar

Dwarf Juniper ....

Western Juniper

Savin Tree

Juniper; Savin ....

$\begin{array}{ll}66 & 66\end{array}$

European Larch.

Japanese Larch

Western Larch

Sibirian Larch

Incense Cedar

White Spruce

" "

Engelmann Spruce

Norway Spruce

Swamp or Black Spruce

Blue Spruce

Red or Black Spruce

Austrian Pine

Swiss Stone Pine

Coulter Pine

Japanese Red Pine

Bank's Pine

Shortleaf or Yellow Pine

Pinion; Nut Pine

Himalayan Pine

Limber Pine

Monterey Pine

Jeffrey Pine

Sugar Pine

Corsican Pine

Seaside Pine

Formosa Pine

Colorado

Silver or Western White Pine .... Pacific Coast

Dwarf Mountain Pine
Rocky Mountains

Pacific Coast

New England

Colorado

Pacific Coast

Japan

Pacific Coast

Pacific Coast

Pacific Coast

Europe

Germany

Europe

Pacific Coast

Southern States

Pacific Coast

Japan

Colorado

New England

Colorado

Colorado

Europe

European Seed

Southern States

Northern States

Middle Northwest

Germany

Japan

Middle Northwest

Europe

Pacific Coast

New England

Black Hills

Foreign

Germany

Middle Northwest

Colorado

Pacific Coast

New England

Germany

Germany

Pacific Coast

Japan

Middle Northwest

Southern States

Pacific Coast

Colorado

Pacific Coast

Pacific Coast

Pacific Coast

Germany

France.

Japan

Pacific Coast

Germany

$\$ 4.50$

11.00

1.50

2.00

2.25

1.50

3.50

3.00

3.50

4.00

1.00

1.00

2.50

2.75

4.00

1.25

.75

2.00

.90

1.25

2.00

1.50

.40

.50

.75

15.00

1.50

3.00

20.00

3.00

2.75

3.50

3.50

2.00

3.25

1.25

1.10

3.25

3.25

4.00

3.25

1.25

.75

4.00

2.00

4.25

400.00

4.00

1.75

2.25

3.00

2.00

3.00

1.50

1.50

.60

2.00

2.50

3.50

2.25 
Origin of Seed

MURRAYANA “Oreg. Com.” PALUSTRIS Mill.

PONDEROSA Laws.

RESINOSA Ait.

RIGIDA Mill.

STROBUS Linn.

SYLVESTRIS A.

TAEDA Linn.

THUMBERGII Parl.

PSEUDOTSUGA TAXIFOLIA Britt. or DOUGLASI Carr. TAXIFOLIA Britt. or DOUGLASII Carr.

SEQUOIA SEMPERVIRENS Englm. WASHINGTONIANA Sudw.

TAXODIUM DISTICHUM Rich.

TAXUS BACCATA Linn. BREVIFOLIA Nutt.

or CUSPIDATA Sieb..

THUJA OCCIDENTALIS Linn. PLICATA ORIENTALIS Linn.

TSUGA CANADENSIS Carr CAROLINIANA Englm. HETEROPHYLLA Sarg. MERTENSIANA Carr. or PATTONIANA Englm. or GIGANTEA Deen.
Lodgepole Pine Pacific Coast Longleaf Pine

Red Pine

Pitch Pine

White Pine.

Scotch Pine

Loblolly Pine

Japanese Black Pine

Douglas Spruce

Douglas Spruce

Redwood

Big Tree

Bald Cypress

European Yew

Pacific Yew

Arborvitae; White Cedar

Giant Arborvitae ...

Chinese Arbortivae...

Hemlock

Carolina Hemlock

Western Hemlock

Black or Mountain Hemlock
Western Yellow Pine
Southern States

Rocky Mountains

Middle Northwest

New England

New England

Europe

Germany

Southern States

Japan

Rocky Mountains

Pacific Coast

Pacific Coast

Pacific Coast

Southern States

Germany

Pacific Coast

New England

New England

Southern States

Pacific Coast

Rocky Mountains

\section{BROAD-LEAVED TREE SEEDS (Deciduous)}

ACER CAMPESTRE Linn. DASYCARPUM Ehr.

or SACCHARINUM Linn.

JAPONICUM Thumb.

NEGUNDO Linn..

PALMATUM var. Atropurpureum, V. H

PENNSYLVANICUM Linn.

PLATANOIDES Linn.

PSEUDO-PLATANUS Linn.

RUBRUM Linn.

SACCHARUM Marsh.

AESCULUS GLABRA Willd. HIPPOCASTANUM Linn. OCTANDRA Marsh.

or FLAVA Ait.

.English Cork Maple

Silver Maple

Japanese Maple

Boxelder

Japanese Purple Maple

Striped Maple

Norway Maple

Red Maple

Sugar Maple

Europe .

New England

Japan

New England

Japan

New England

New England

New England

Ohio Buckeye or Am. Horse Ch'nt New Enghend

European Horse Chestnut ...... New England

Yellow Buckeye

Middle Northwest

Tree of Heaven

Middle Northwest

European Alder

Europe

Speckled or Hoary Alder

Japanese Alder

INCANA Willd.

JAPONICA

OREGONA Nutt.

AMELANCHIER CANADENSIS J. \& C.

ASIMINA TRILOBA Linn..

BETULA ALBA Linn.

LENTA Linn.
LUTEA Michx.
NIGRA Linn.

PAPYRIFERA Marsh.

POPULIFOLIA
Red Alder (cleaned)

Serviceberry

Papaw

European Birch

Sweet or Cherry Birch (cleaned) New England

Yellow Birch (cleaned ......... New England

Black Birch (cleaned)

Southern States

Paper or Canoe Birch (cleaned)

Gray Birch
New England

New England

New England
$\$$

150.00

550.00

175.00

140.00

275.00

260.00

215.00

.75

2.00

.40

2.50

1.75

.50

.60

1.25

.75

.35

.35

65.00

10.00

10.00

.35

.50

10.00 
CALICARPA AMERICANA JAPONICA

CARPINUS BETULUS Linn. CAROLINIANA Walt.

CARYA (See Hicoria)

CASTANEA DENTATA Borkh. or AMERICANA Rafin PUMILA Linn.

CATALPA SPECIOSA Warder. CELTIS OCCIDENTALIS Linn. CERCIS CANADENSIS Linn. CORNUS FLORIDA Linn.

MASCULA Linn. CORYLUS AMERICANA Walt. CRATAEGUS COCCINEA Linn. CORDATA Ait. CRUSGALLI Linn.

DIOSPYROS VIRGINIANA Linn.

EUCALYPTUS GLOBULUS Lab.*

*(Quotations on other species of Eucalypti... Blue Gum.

American Sweet Chestnut

Chinquapin

French Mulberry.

Japanese Mulberry

European Hornbeam

Blue Beech.

Guaranteed True Hardy Catalpa

Hackberry, Sugarberry

Redbud

Flowering Dogwood

European Dogwood

Hazelnut

Scarlet Haw (cleaned)

Washington Haw (cleaned)

Cockspur (cleaned)

Persimmon

Blue Gum.

FAGUS ATROPUNICEA Sudw.

or FERRUGINEA Ait.

SYLVATICA Linn.

SYLVATICA PURPUREA

FRAXINUS AMERICANA Linn.

EXCELSIOR Lam.

LANCEOLATA Borkh.

or VIRIDIS Michx. NIGRA Marsh.

or SAMBUCIFOLIA Lam. PENNSYLVANICA Marsh.

or PUBESCENS Lam.

American Beech

European Beech

Purple-Leaved Beech

White Ash (Guarantecl true)

European Ash

Origin of Seed

Green Ash

Black Ash

Red Ash Honey Locust

".

Linn

Kentucky Coffee Tree

GYMNOCLADUS DIOICUS K. Koch.
or CANADENSIS Lam.

GYMNOCLADUS DIOICUS K. Koch. or CANADENSIS Lam.

HAMMAMELIS VIRGINIANA Linn.

HICORIA ALBA Britt.

or CARYA TOMENTOSA Nutt.

HICORIA GLABRA Britt.

or CARYA PORCINA Nutt.

HICORIA GLABRA Britt.

or CARYA PORCINA Nutt.

HICORIA LACINOSA Sarg.

or CARYA SULCATA Nutt.

HICORIA LACINOSA Sarg.

or CARYA SULCATA Nutt.

HICORIA MINIMA Britt.

or CARYA AMARA Nutt.

HICORIA OVATA Britt.

or CARYA ALBA Nutt.
Kentucky Coffee Tree

Witch Hazel

Mocker Nut (Hickory)

.Pignut (Hickory)

Pignut (Hickory) . . .

Big Shellbark (Hickory)

Big Shellbark (Hickory)

Bitternut; Swamp Hickory

Shellbark; Shagbark Hickory .... New England

New England

New England
Europe

Japan

Germany

Middle Northwest

New England

Southern States

Indiana

New England

Southern States

New England

Southern States

Europe

Middle Northwest

New England

New England

Middle Northwest

Southern States

Pacific Coast

Eastern States

Europe

Europe

New England

Europe

Middle Northwest

Middle Northwest

Middle Northwest

Middle Northwest

Foreign Seed

Northern States

Southern States

Southern States

Southern States

Southern States

North Eastern Statcs 
HICORIA OVATA Britt. or CARYA ALBA Nutt.

HICORIA PECAN Britt.

or CARYA OLIVAEFORMIS Nutt.

ILEX OPACA Ait.

JUGLANS CINEREA Linn. NIGRA Linn.

LARIX (See under Coniferous Tree Seeds)

LIQUIDAMBAR STRYACIFLUA Linn.

LIRIODENDRON TULIPIFERA Linn.

MAGNOLIA ACUMINATA Linn. FOETIDA Sarg.

or GRANDIFLORA Loud. TRIPETALA Linn.

MORUS ALBA Linn.

ALBA TATARICA Loud.

OSTRYA VIRGINIANA K. Koch.

PLATANUS OCCIDENTALIS Linn.

ORIENTALIS Linn.

PRUNUS AMERICANA Marsh. MARITIMA Wang.

PENNSYLVANICA Linn.

SEROTINA Ehr.

VIRGINIANA Linn.

PYRUS AMERICANA D. C.

QUERCUS ACUMINATA Sarg.

ALBA Linn.

COCCINEA Muench.

IMBRICARIA Michx.

LYRATA Walt.

MACROCARPA Michx.

MICHAUXII Nutt.

MINOR Sarg.

PALUSTRIS Muench.

PENDUNCULATA Ehrh.

PHELLOS Linn.

PLATANOIDES Sudw.

or BICOLOR Willd.

PRINUS Linn.

ROBUR Linn.

RUBRA Linn.

SESSILIFLORA Salish.

VELUTINA Lam.

or TINCTORIA Bartr.

RHAMNUS CATHARTICA L.

RHUS TYPHINA Linn.

ROBINIA PSEUDACACIA Linn.

SASSAFRAS SASSAFRAS Linn.

TILIA AMERICANA Linn.

GRANDIFOLIA Ehrh.

HETEROPHYLLA Veni.

PARVIFOLIA Ehrh.

TOXYLON POMIFERUM Raf.

ULMUS AMERICANA Linn.

CAMPESTRIS Linn.

VIBURNUM ACERIFOLIUM Linn. CASSINOIDES Linn.

DENTATUM Linn.

OPULUS Linn.
Shellbark; Shagbark Hickory

Pecan

American Holly

Butternut

Black Walnut

Sweet Gum

Tulip Tree; Yellow Poplar.

Cucumber Tree

Evergreen Magnolia

Umbrella Tree

White Mulberry

Russian Mulberry...

Hornbeam

Sycamore; Buttonwood

Oriental Planes

Wild Plum

Beach Plum

Wild Red Cherry

Black Cherry

Choke Cherry

Mountain Ash

Chinquapin or Chestnut Oak

White Oak

Scarlet Oak

Shingle Oak

Overcup Oak

Bur Oak

Cow Oak

Post Oak

Pin Oak

European Peduncle Oak

Willow Oak

Swamp White Oak

Chestnut Oak

English Oak

Red Oak

English Sessile Oak

Yellow Bark Oak

Common Buckthorn

Staghorn Sumach

Black or Yellow Locust

\section{Sassafras}

Basswood

Large-leaved European Linden

White Basswood

Small-leaved European Linden

Osage Orange

White or American Elm

English Elm

Dockmakie

Withe-rod.

Arrowwood

Cranberry Tree
Origin of seed

Southern States

Southern States

North Eastern States

New England

New England

Middle Northwest

Middle Northwest

Middle Northwest

Southern States

Southern States

Europe

Middle Northwest

.New England

New England

Southern States

New England

Middle Northwest

New England

North Eastern States

Middle Northwest

New England

New England

Southern States

New England

New England

Southern States

Northeastern States

Middle States ...

Southern States

Southern States

Southern States

American Seed

. Southern States

New England

Middle Atlantic States

American Seed

New England

American Seed

New England

Europe ..... .

New England

Middle Northwest

Europe ..

Southern States

New England

Europe

Southern States

Europe . .

Middle Northwest

New England

Europe 


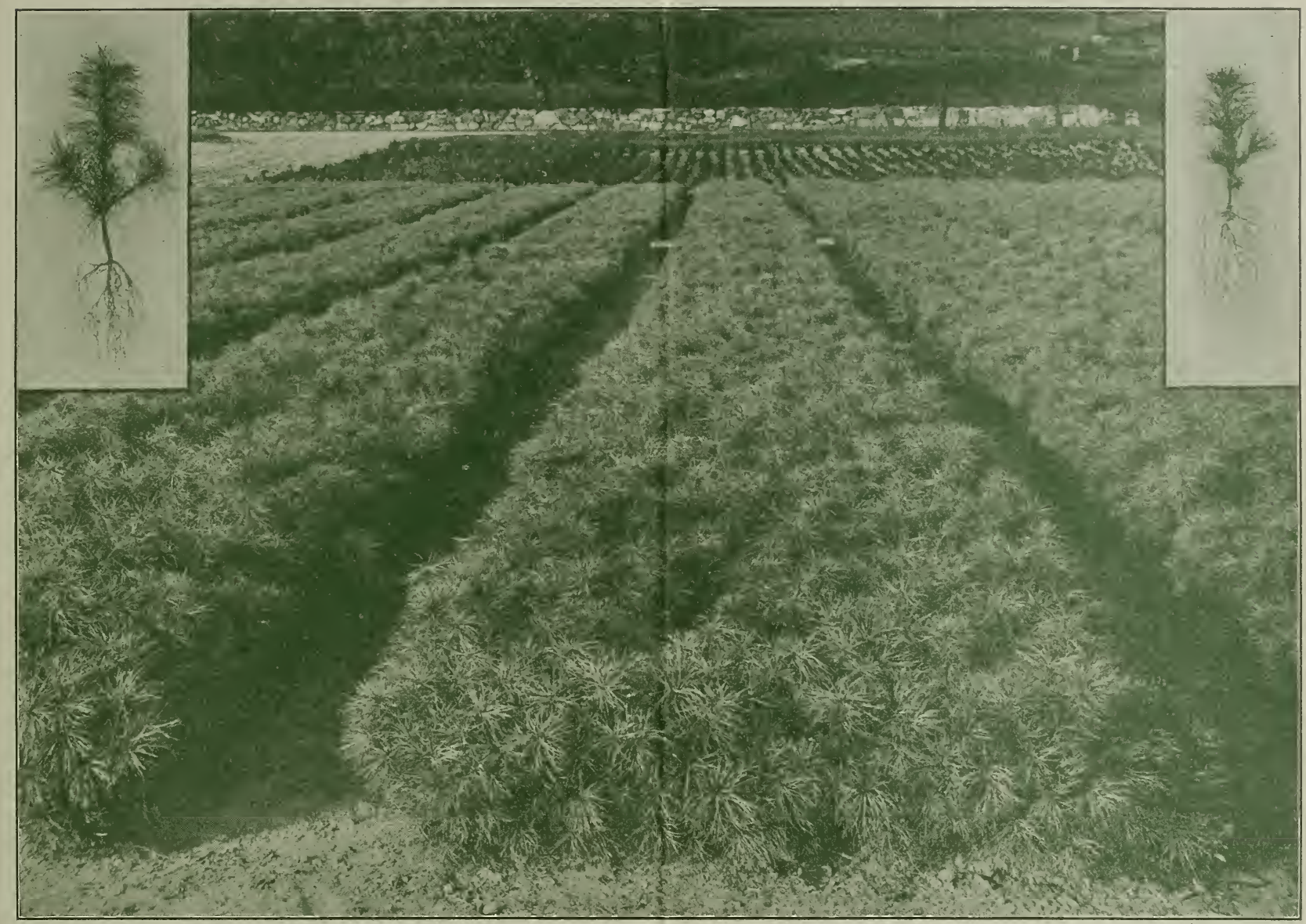

Three-Year Seedling White Pine (Pinus Strobus) at Little Tree Farms

Every tree grown from seed in the open and wintered in the open without protection under natural and scientific conditions

ALL SEED COLLECTED BY OUR OWN MEN OR BY TESTED COLLECTORS FROM REGIONS SPECIFIED BY US 


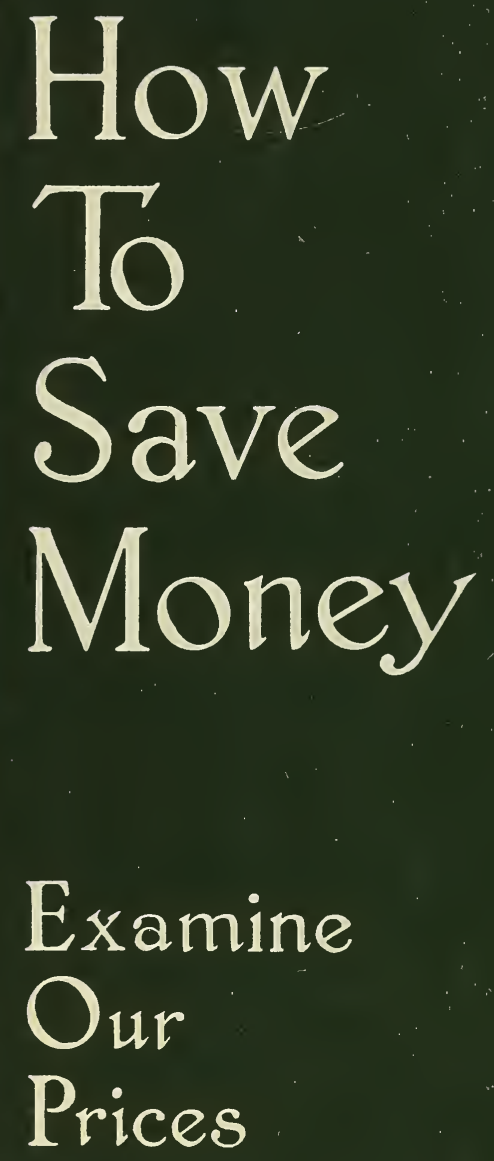

